\title{
PERANCANGAN APLIKASI PENGENDALI LISTRIK BERBASIS WEB MENGGUNAKAN MIKROKONTROLER AT89251
}

\author{
AAN RISDIANA \\ Program Studi Informatika \\ Fakultas Teknik dan Ilmu Komputer \\ Universitas Indraprasta PGRI \\ Jl. Nangka No. 58 C, Tanjung Barat, Jagakarsa, Jakarta Selatan 12530 \\ Email : Risdi_aan@live.com
}

\begin{abstract}
Abstrak. Sistem berbasis web menggunakan mikrokontroler AT89S51adalah sebuah rangkaian elektronika yang disupport dengan aplikasi teknologi informatika karena menggunakan beberapa aplikasi komputer untuk menjalankannya. Sistem ini menggunakan beberapa perangkat utama dan tambahan diantaranya aplikasi Visual Basic, mikrokontroler, dan relay sebagai controller penghantar switch pada lampu yang akan dikendalikan. Dengan sistem ini dapat mengendalikan arus listrik secara jarak jauh dengan memanfaatkan jaringan internet, menggunakan website dan sistem ini masih dalam tahap percobaan untuk direalisasikan ke masyarakat luas.
\end{abstract}

Kata Kunci: AT89S51, sistem kendali listrik, web

Abstract. Web-based system using microcontroller AT89S51 is an electronic circuit that is supported with the application of information technology, because it uses some computer application to run it. This system uses several devices and additional applications include Visual Basic, microcontroller, and relay as controller of carriage switches in the lights will be controlled. By using this system, electricity can be controlled remotely through internet, using website. However, this system is still in the experimental stage to be implemented into the wider community.

Keywords: AT89S51, electric control system of microcontroller, web

\section{PENDAHULUAN}

Dengan kemajuan teknologi yang semakin pesat, maka meningkat pula kebutuhan dan fasilitas-fasilitas yang mendukung manusia dalam menyelesaikan tugas-tugasnya. Saat ini orang semakin sibuk, semakin maju serta saling bersaing. Waktu merupakan sesuatu yang sangat berharga, orang pun sibuk berkutat dengan segala urusannya, hampir tidak ada waktu lupa bahkan ceroboh untuk memerikasa keadaan rmah. Dengan kata lain ia tidak mau disibukkan dengan urusan-urusan rumah yang menurutnya kurang vital dibandingkan dengna kesibukan yang selalu menunggu. 


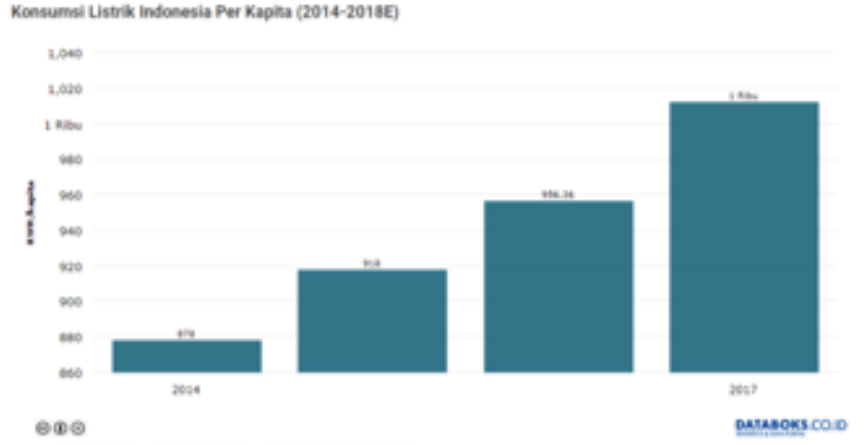

Gambar 1. Penggunaan Konsumsi Listrik Per Kapita (2014-2018) Sumber : Kementrian ESDM

Selain itu, tarif listrik semakin tahun bukannya semakin turun tetapi sebaliknya semakin tahun memperlihatkan kecenderungan semakin meningkat, sehingga menuntut pemakai listrik harus semakin cerdik dalam mensiasati penggunaannya sebagai sumber daya peralatan listriknya.

Berdasarkan analisis contoh kejadian dan grafik penggunaan konsumsi listrik tersebut, maka diperlukan suatu peralatan yang dapat mengendalikan peralatan listrik secara jarak jauh dimana peralatan pengendali tersebut berbasis web dan mikrokontroler AT89s51 sebagai media transmisinya. Dengan teknologi pengendali ini, seseorang tidak perlu pulang ke rumah hanya untuk mengecek peralatan listriknya seperti lampu, $\mathrm{AC}$, lemari es, dan peralatan listrik lainnya untuk mengetahui apakah dalam kondisi menyala atau mati.

\section{METODE}

Model prototype merupakan teknik mengumpulkan informasi tertentu tentang kebutuhankebutuhan informasi pengguna secara cepat. Pengguna seringkali menjelaskan sekumpulan sasaran umum perangkat lunak, namun tidak mengidentifikasikan kebutuhan input, proses, dan output. Developer tidak yakin akan efisiensi dari suatu sistem operasi. Dalam situasi seperti ini, model prototyping bisa memberikan pendekatan terbaik.

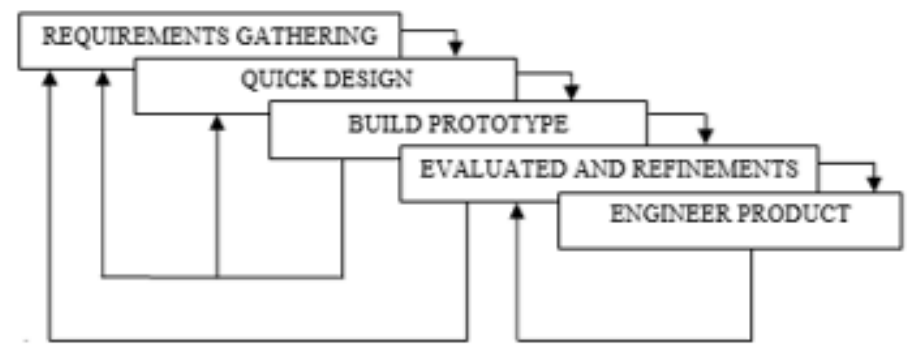

Gambar 2. Model Prototyping

Adapun metode pengembangan sistem meliputi analisa kebutuhan, studi keputaskaan, perancangan sistem, implementasi, evaluasi sistem, dan pengujian sistem.

\section{Studi Pustaka}

Dilakukan terhadap pustaka yang berkaitan dengan pengendalian penggunaan daya listrik, serta komponen yang digunakan pada penelitian. 


\section{Rancang Bangun Piranti Lunak}

Melakukan studi kasus dan referensi untuk proses perancangan pada perangkat lunak, merancang web dengan menggunakan bahasa pemrograman PHP, membangun sebuah server dengan menggunakan script pada aplikasi visual basic serta membuat beberapa tabel untuk pengisian database dimana database tersebut yang menampung data informasi untuk ditampilkan baik dalam server maupun dalam web sehingga database tersebut menjadi penghubung diantara keduanya serta mengatur (setting) mikrokontroler dengan memberikan perintah bahasa pemrograman assembly sebagai instruksi untuk mengendalikan arus listrik. Berikut adalah rincian aplikasi yang digunakan untuk rancang bangun sistem kendali listrik menggunakan mikrokontroler.

- Sistem Operasi

- Web design

- Browser internal

- Database\& web design view

- Server kendali

- Penghubung server \& database

- Driver USB serial

- Setting Mikrokontroler

Adapun kebutuhan perangkat keras pada perancangan tersebut adalah:

- Microprosesor

- Ram

: Intel Atom N450 - $1.66 \mathrm{Ghz}$

- Hard disk external

: $1 \mathrm{~GB}$

- Mother Board

- Monitor

- Keyboard

- Mouse

- Mikrokontroler

- USB serial
: Windows

: Dreamweaver 8

: Mozila Firefox

: Xampp/Localhost

: Visual Basic 6

: MySQL ODBC 3.51

: Rigel Read 5.1
: PL-2303USB-Serial Driver

: $230 \mathrm{~GB}$

: HP Tek Computer

: LCD 10,1 inc

: 120 key

: Optical

: AT89s51

: PL-2303

\section{Struktur Navigasi Web}

Struktur navigasi dari aplikasi web yang berguna untuk menyimpan data-data yang diperlukan oleh sistem. Adapun struktur navigasi yang digunakan pada aplikasi web dapat dilihat pada gambar sebagai berikut:

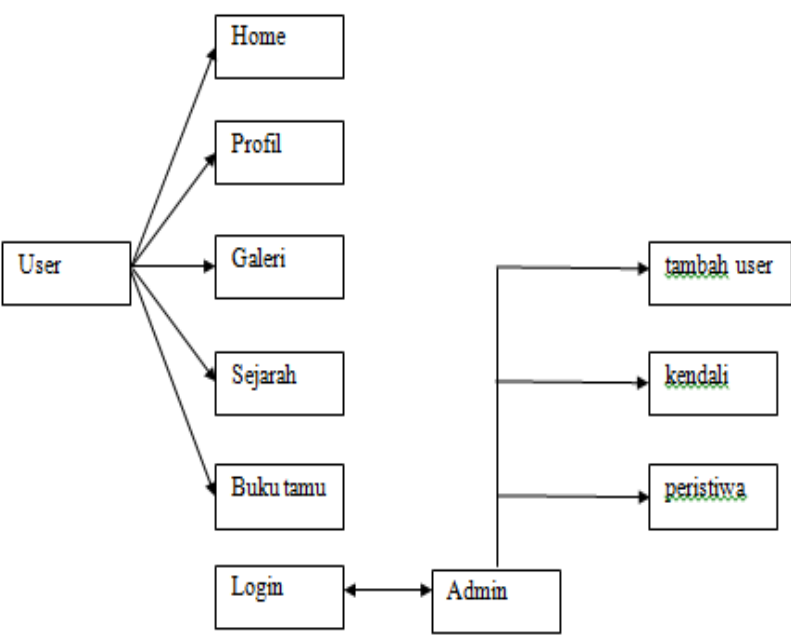

Gambar 3. Struktur Navigasi Web 
Dari struktur navigasi pada gambar 3 dapat dilihat user dapat mengakses fitur yang dibuat, sedangkan tambah user, kendali, dan peristiwa hanya bisa dilakukan oleh admin setelah berhasil login. Admin juga dapat mengedit atau menghapus isi pesan yang terdapat pada buku tamu jika terjadi penyalahgunaan pada pengunjung.

\section{Rancangan Miniatur}

Merancang tampilan bentuk rumah beserta tiga buah lampu yang sudah disesuaikan pada design yang terdapat pada web dan server merancang rangkaian elektronika yang akan digunakan pada miniatur diantaranya merancang rangkaian relay, adaptor, USB Serial, driver USB, mikrokontroler, dan lain-lain.

\section{Perangkat Tambahan}

Setelah aplikasi pada PC dan rangkaian listrik selesai, ada beberapa perangkat tambahan untuk mendukung dan menghubungkan antara sensor dengan aktuator, diantaranya adalah:

\section{USB Serial}

Menghubungkan antara perangkat lunak dan perangkat keras diperlukan USB Serial yang support dengan OS yang digunakan karena peneliti memakai windows XP untuk pengoperasian maka diperlukan driver untuk membacanya yaitu PL-2303 USB Serial Driver.

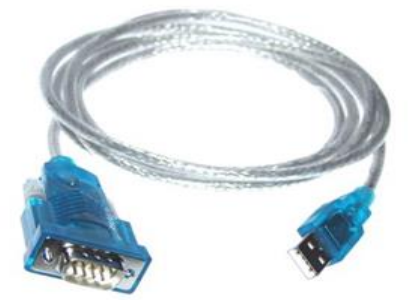

\section{Adaptor}

Gambar 4. Kabel USB Serial

Prinsip kerja adaptor adalah merubah tegangan AC (Alternating Current) menjadi tegangan DC (Direct Current). Komponen adaptor adalah transformator, diode, dan kondesator.

\section{Transformator}

Transformator atau sering disebut trafo adalah alat untuk mentransfer tegangan AC dari gulungan kawat lainnya. Kawat yang dipakai biasana menggunakan kawat email, sedangkan untuk inti besi biasanya menggunakan lapisan-lapisan pelat besi. Selain itu transformator juga berfungsi untuk menaikkan tegangan listrik. Trafo jenis ini disebut trafo step up dan yang menurunkan tegangan listrik disebut trafo step down.

\section{Diode}

Diode berfungsi sebagai penyearah yang dapat mengubah tegangan AC menjadi DC. Rangkaian penyearah, setengah gelombang dan penyearah gelombang penuh.

Kondensator

Kondensator berfungsi sebagai filter, Kondensator biasanya menggunakan kondesator ELKO (elektrolit Kondensator). Arus bolak balik yang melewati penyearah, masih harus diratakan menggunakan kondesator. Pada pembuatan adaptor biasanya menggunakan ELKO.

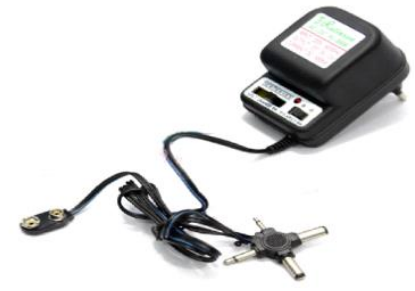

Gambar 5. Adaptor 


\section{Relay}

Relay adalah suatu peranti yang bekerja berdasarkan elektromagnetik untuk menggerakkan sejumlah kontraktor (saklar) yang tersusun. Kontraktor akan tertutup (ON) atau terbuka (Off) karena efek induksi magnet yang dihasilkan kumparan (induktor) ketika dialiri arus listrik. Berbeda dengan saklar dimana pergerakan kontraktor (On/Off) dilakukan manual tanpa perlu arus listrik.

Sebagai komponen elektronika, relay memiliki peran penting dalam sebuah rangkaian elektronika dan rangkaian listrik untuk menggerakkan sebuah perangkat yang memerlukan arus besar tanpa terhubung langsung dengan perangkat pengendali yang mempunyai arus kecil. Dengan demikan relay dapat berfungsi sebagai pengaman.

Dalam perancangan aplikasi ini, peneliti menggunakan relay kaki lima untuk control penghantar switch pada lampu yang akan dikendalikan.

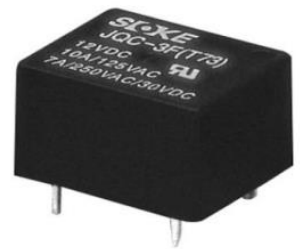

Gambar 6. Relay

\section{Prinsip Sistem Kerja Mikrokontroler}

Setiap user baik mengendalikan melalui web ataupun server akan mengirim informasi data yang terkoneksi dengan database sehingga perintah menyalakan atau mematikan lampu tergantung pada database membaca data kondisi terakhir. Prinsip kerja mikrokontroler seperti gambar 5 berikut:

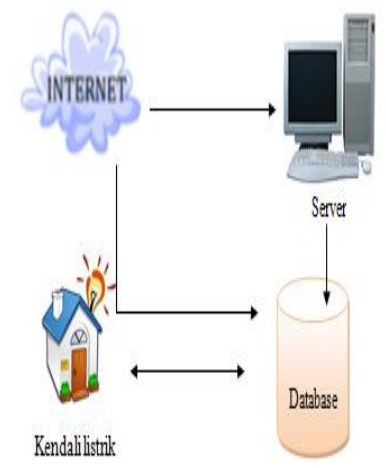

Langkah 1

Gambar 7. Prinsip Sistem Kerja Mikrokontroler

Berdasarkan nilai yang berada pada register Program Counter, mikrokontroler mengambil data pada ROM dengan alamat sebagaimana yang tertera pada register Program Counter. Selanjutnya isi dari register Program Counter ditambah dengan satu (Increment) secara otomatis. Data yang diambil pada ROM merupakan urutan instruksi program yang telah dibuat sebelumnya oleh pengguna.

Langkah 2

Instruksi yang diambil tersebut diolah dan dijalankan oleh mikrokontroler. Proses pengerjaan bergantung pada jenis instruksi, bisa membaca, mengubah nilai-nilai pada register, RAM, isi Port, atau melakukan pembacaan dan dilanjutkan dengan pengubahan data.

Langkah 3

Program Counter telah berubah nilainya (baik karena penambahan otomatis pada langkah 1, atau karena pengubahan-pengubahan pada langkah 2). Selanjutnya yang dilakukan oleh 
mikrokontroler adalah mengulang kembali siklus ini pada langkah 1. Demikian seterusnya hingga power dimatikan.

\section{Perancangan Aplikasi di Visual Basic}

Perancangan aplikasi di visual basic dibuat sesuai dengan kebutuhan sistem, yaitu terkoneksi dengan database, mikrokontroler, dan web. Konsep perancangan tampilan home setelah login hanya berisi denah rumah yang sebelumnya harus menyesuaikan diport mana USB dimasukkan, disertai tombol lampu yang akan dikendalikan. Selain itu, menyediakan tampilan informasi keadaan lampu setiap tiga detik sekali.

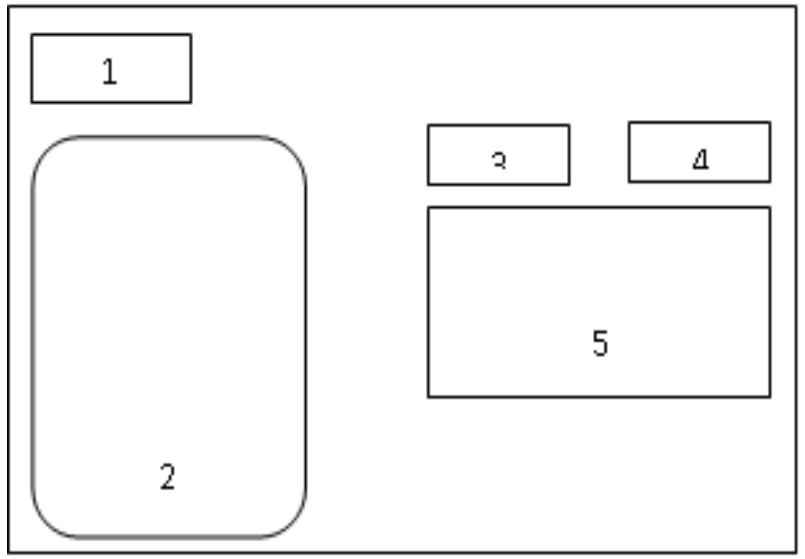

Gambar 8. Rancangan Antarmuka di Visual Basic

Keterangan gambar 8:

\section{Connect port}

Connect port merupakan koneksi antara USB serial ke mikrokontroler, port disesuaikan dengan USB mana kita masukan, jika number port tidak sesuai dengan slot USB yang dimasukan maka akan timbul pesan error, dan terdapat perintah connect ke aplikasi dan disconnect aplikasi.

\section{Denah Peta}

denah peta adalah denah kendali atau ruangan yang sudah didesain sesuai dengan susunan lampu yang terdapat pada perangkat elektronik. dalam peta kendali terdapat icon tiga buah lampu yang berfungsi sebagai tombol indicator apakah lampu dalam keadaan menyala atau mati.

\section{Reset}

Tombol reset berfungsi sebagai mematikan seluruh lampu yang menyala

\section{Kembali}

Tombol kembali berfungsi untuk kembali ke menu sebelumnya yaitu login

Tabel

Tabel pada aplikasi ini berfungsi sebagai informasi keadaan lampu setiap tiga detik sekali dsan member informasi apakah lampu dikendalikan oleh desktop ataupun web online.

\section{Pengujian Alat}

Pada tahap ini dilakukan pengujian dengan cara mematikan dan menyalakan lampu baik itu melalui server ataupun melalui web dan terdapat laporan dalam database tentang kondisi lampu terakhir. Hasilnya, lampu yang dikendalikan sesuai dengan peta kendali yang telah dibuat baik melalui server ataupun web, namun jika terjadi kesalahan, maka peneliti melakukan koreksi pada tahap perancangan.

\section{HASIL DAN PEMBAHASAN}

Berikut adalah tampilan login web pada gambar 9: 


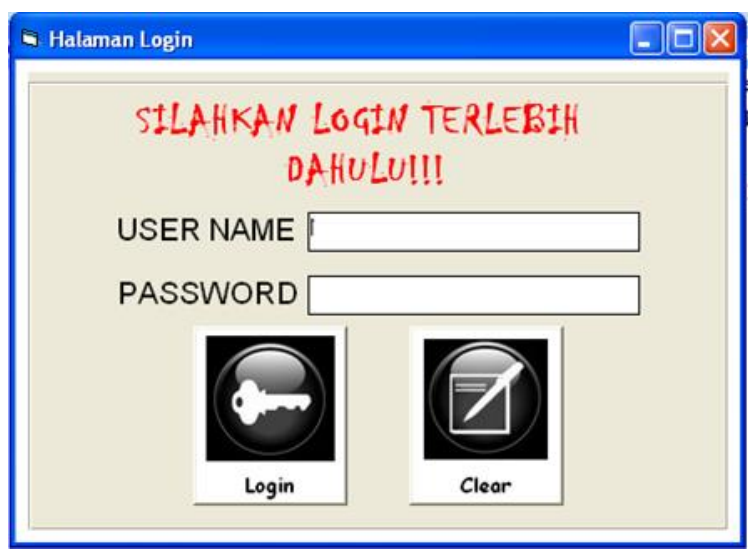

Gambar 9. Tampilan Login pada aplikasi VB

Setelah login, berikut tampilan peta kendali pada gambar 10:

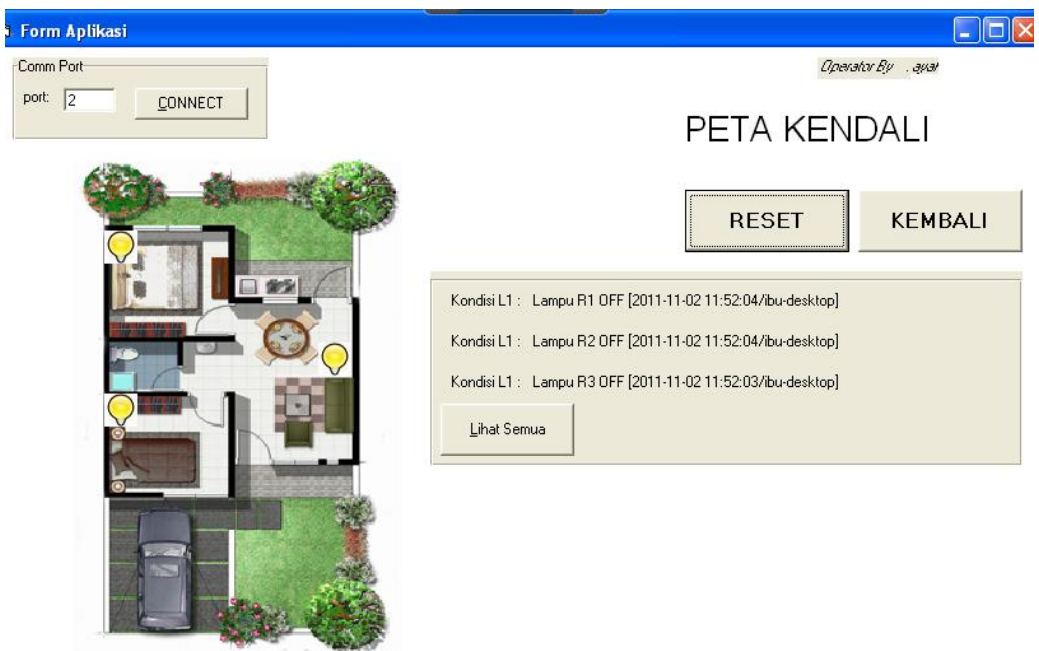

Gambar 10. Tampilan Aplikasi Peta Kendali pada VB

Dalam peta pada gambar 10 terdapat beberapa data yang harus dikirim kedalam database untuk menginformasikan ke dalam web, untuk memulainya adalah menggunakan tools $A D O D C$ yang terdapat pada fitur Visual Basic. Dalam dalam tools tersebut terdapat properties yang akan di setting connection string dan user yang dibuat akan disesuaikan ke dalam database conector.

Untuk mengkoneksikan Visual Basic ke dalam database diperlukan sebuah aplikasi database sebagai penghubung, penulis menggunakan MySQL ODBC 3.51 driver. Langkah pertama setelah aplikasi tersebut diinstal adalah mensetting konfigurasi yang ada didalamnya dengan memilih control panel kemudian administrative tools, serta pilih data sources (ODBC) dan pilih sistem DSN untuk melakukan setting, berikut adalah gambar 11 saat setting MySQL ODBC 3.51 driver: 


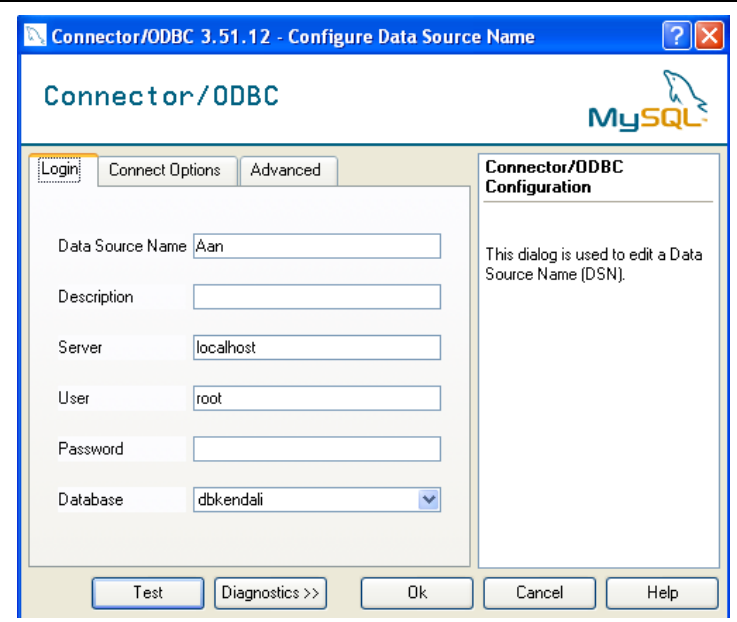

Gambar 11. Setting MySQL ODBC 3.51 Driver

Setelah selesai melakukan setting, langkah selanjutnya adalah pilih test untuk memastikan apakah database terkoneksi atau tidak, jika test berhasil maka informasi yang diinput melalui VB akan terkoneksi dengan database yang telah disetting sebelumnya.

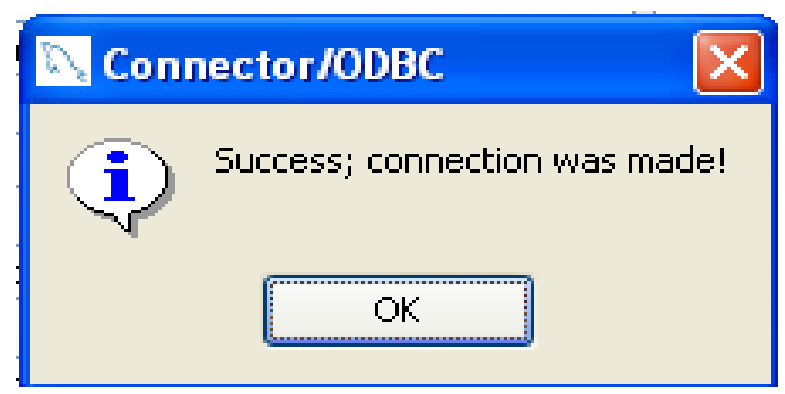

Gambar 12. Connection Test pada ODBC 3.51 Driver

\section{Database}

Dalam perancangan WEB ataupun server/desktop masing masing terdapat informasi yang terkoneksi dengan database, yang didalamnya terdapat beberapa table untuk diproses oleh admin. penulis membuat dbkendali dan memiliki enam table yang diterima saat web mengirim informasi, table tersebut adalah :

\section{$T b \_$login}

Database berisi tentang admin dan password yang bisa mengakses kendali yang terdapat pada web.

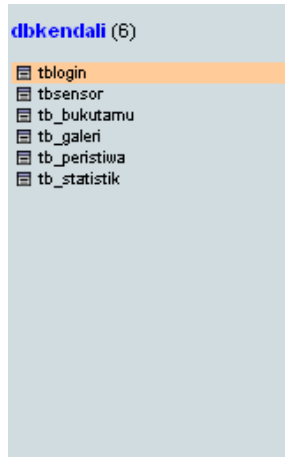

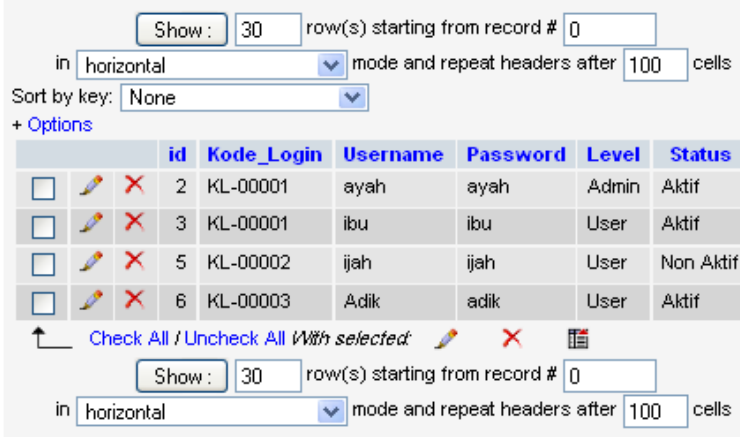

Gambar 13. Tb_login 
Tb_sensor

Tbsensor adalah informasi record keadaan terakhir lampu, untuk pengisian database, server melakukan record selama tiga detik sekali sesuai dengan keadaan lampu.

Form yang terdapat pada tbsensor adalah : kode_sensor, posisi lampu dikendalikan, apakah melalui web online atau desktop, oleh, adalah field yang berisi siapa admin yang menyalakan atau mematikan lampu, jam, tanggal dan deskripsi adalah informasi static sesuai dengan update nya, data, ialah lampu mana yang sudah dinyala/matikan, sedangkan id adalah penomoran urut pada database.

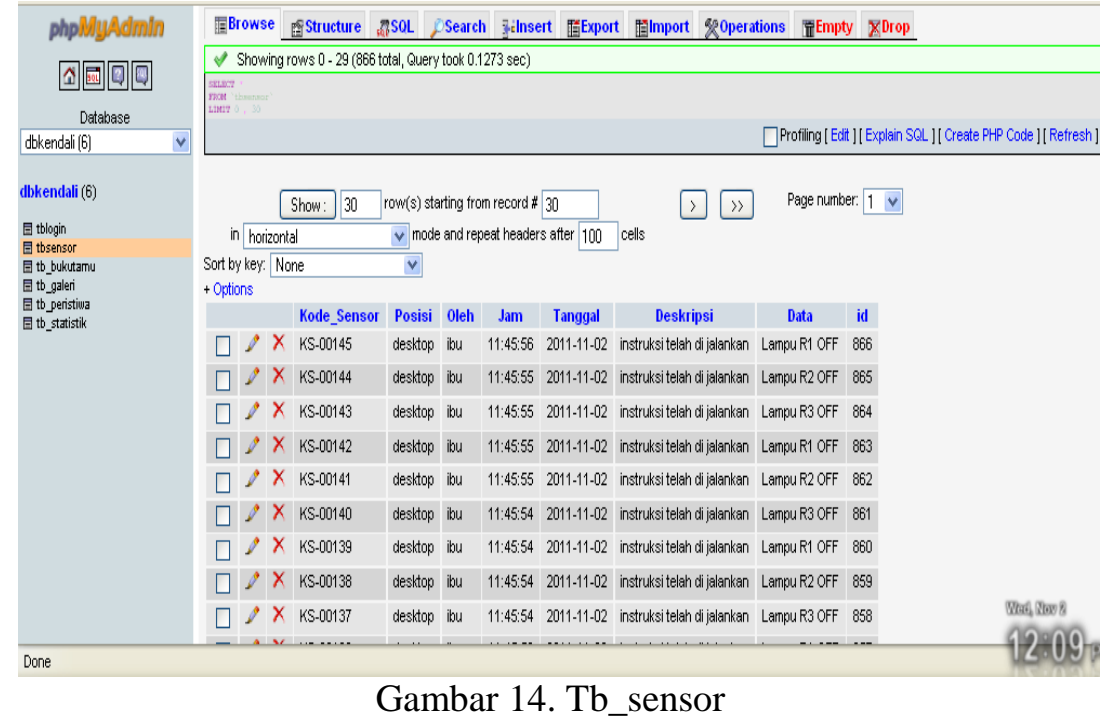

\section{Tb_bukutamu}

table tb_bukutamu adalah database informasi yang diisi oleh pengunjung, admin dapat membalas pesan yang masuk melalui localhost, field yang terdapat pada tb_bukutamu adalah : kode_bukutamu, tanggal, nama, telpon, email, pesan, status_bukutamu.

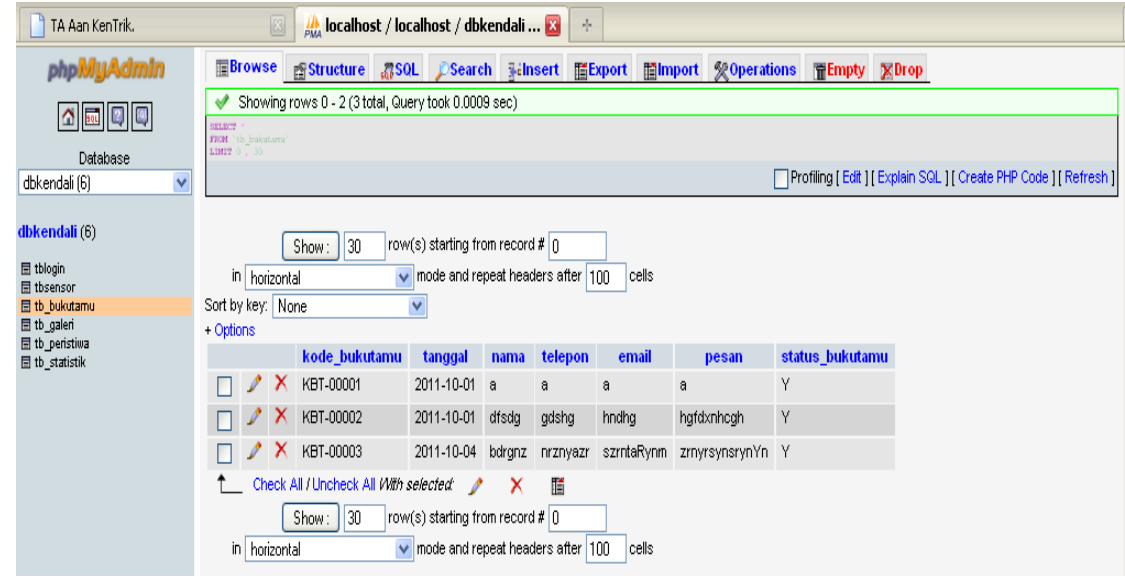

Tb_galeri

Gambar 15. Tb_bukutamu

Mengisi fasilitas galeri yang ditampilkan pada web, galeri yang ditampilkan oleh penulis adalah berupa foto.

\section{tb_peristiwa}

Merupakan table yang berisi informasi atau pesan - pesan yang dilakukan oleh admin tb_statistik 
Adalah informasi mengenai pengunjung yang secara otomatis record pada table merupakan table yang berisi informasi atau pesan - pesan yang dilakukan oleh admin.

Setiap data yang masuk, admin dapat mengolah dan mengedit data tersebut untuk diproses, database juga sebagai pengirim sinyal ke mikrokontroler untuk mengendalikan listrik.

\section{Setting Mikrokontroler}

Langkah selanjutnya adalah setting pada mikrokontroler, untuk menerima input, mikrokontroler disetting menggunakan software Rigel Read 51 menggunakan bahasa assembly yang kemudian diproses dan diberikan output kedalam relay yang terhubung dengan tiga buah lampu, berikut adalah gambar 16 saat setting pada Read 51.

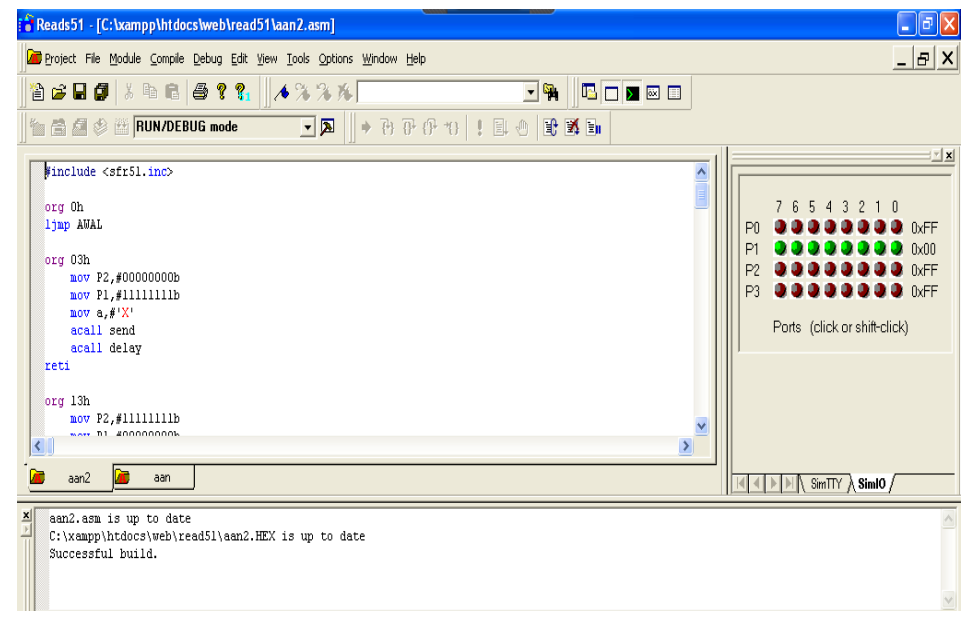

Gambar 16. Setting Mikrokontroler

Setelah mensetting mikrokontroler, berikut hasil rancangan sistem pengendali berbasis web menggunakan mikrokontroler AT89S51 pada gambar 17:

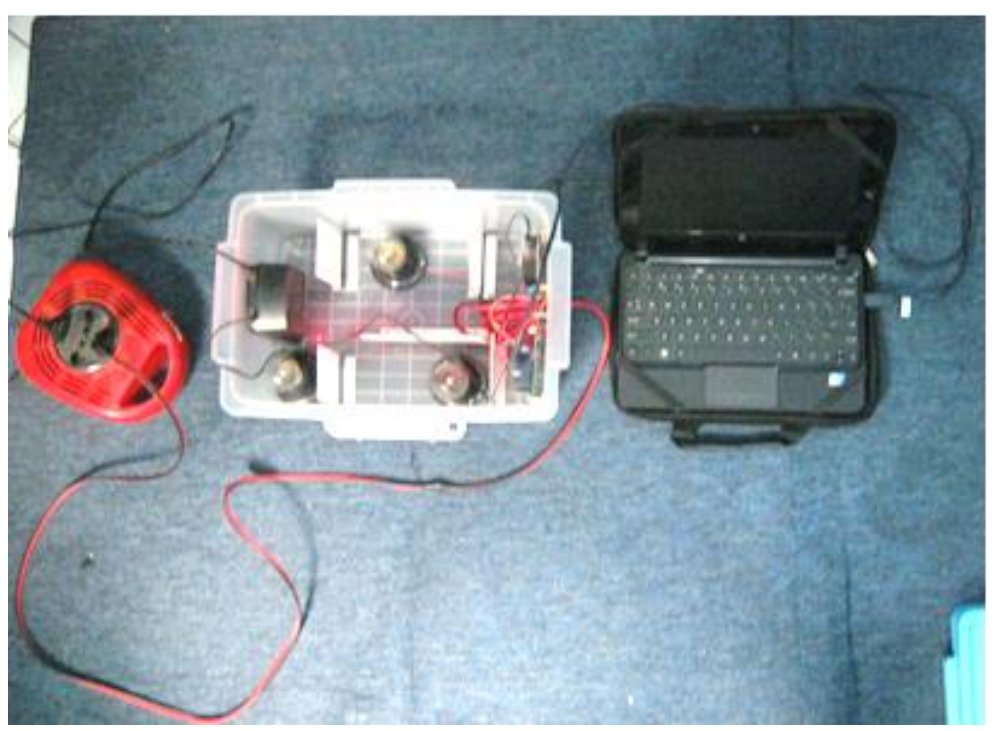

Gambar 17. Hasil Sistem Kendali Listrik Berbasis Web Menggunakan Mikrokontroler 


\section{PENUTUP}

Simpulan

Berdasarkan hasil uji coba sistem yang telah dilakukan terdapat sistem kendali listrik berbasis web dengan menggunakan mikrokontroler AT89s51 dapat berfungsi dengan baik dan sistem aplikasi ini masih dalam tahap percobaan untuk membantu user dalam mengontrol serta mengendalikan arus listrik tanpa harus berada dirumah .

\section{Saran}

Untuk penggunaan database pada server perlu adanya perbaikan metode sehingga tidak terjadi penumpukan data pada setiap detiknya.

\section{DAFTAR PUSTAKA}

AE. Putra, 2002. Belajar Mikrokontroler AT89c51/52/55 Teori dan Aplikasi. Yogyakarta: Gava Media

EP. Agfianto. 2010. Tip dan Trik Mikrokontroller At 89 dan AVR Tingkat Pemula Hingga Lanjut. AE Putra. Yogyakarta: Gava Media.

Bahtiar, Afwan. 2012. Perancangan Penyedia Layanan Pemantau ruangan Untuk Perangkat Bergerak.

Haryadi, Aldi. 2007. Cara Mudah Membangun Sistem Rumah Cerdas. Jakarta.

PJ Iswara, AE Putra. 2012. Sistem Kontrol Keseimbangan Statis Robot Humanoid Joko Klana Berbasis Pengontrol PID. IJEIS (Indonesian Journal of Electronics and Instrumentation Systems).

TK Priyambodo, AE Putra, A. Dharmawan. 2015. Optimizing Control Based on Ant Colony Logic for Quadrotor Stabilization. Electronics and Remote Sensing Technology (ICARES). IEE Research. 